\title{
The Effect of Poetry and Music on Ancient Sports in Iran
}

\author{
O efeito da poesia e da música nos esportes antigos no \\ Irã
}

\section{El efecto de la poesía y la música en los deportes antiguos en Irán}

\author{
iD (9) Bisotoon Azizi \\ Islamic Azad University, Piranshahr, Iran \\ bistonazizi@gmail.com \\ iD (9) Mohammad Mohammadi \\ Malayer University, Malayer, Iran \\ m.mohammadi@malayer.ac.ir \\ (iD Nima Deimary \\ Malayer University, Malayer, Iran \\ N.deimary@malayeru.ac.ir \\ iD \\ Seyed Ali Mir Shahvelad \\ Malayer Scientific-Applied Training Center, Iran \\ mirshahvelad@gmail.coml
}

\begin{abstract}
The purpose of this paper is to investigate the effect of poetry and music on ancient sports in Iran. As a cultural heritage, Iranian traditional gymnasium "Zurkhaneh" can be understood correctly and comprehensively when, in addition to what is seen from the point of view of today's science, it is transcended and measured and analyzed in the field of thought and civilization that has emerged from it. This study was a field and library studies. A review of the poetry literature shows that Iranian ancient sport dates back to the Medes and pre-Islamic era. Among the traditional gymnasium poems, the poems that are related to the praise of God, the praise of the Holy Prophet Mohammed and the
\end{abstract}


praise of Imam Ali, the first Shia Imam, have a special role in the music in the ancient sports. The lyrics and music becomes easier and closer to people's lives, relying on simple and easy principles, to get people to follow the words and to put their words in their minds. The music in ancient sport has been chosen in such a way that the mentor can easily improvise and memorize it. The study on the influence of poetry and music on ancient sports confirms that; traditional gymnasium, as a cultural place and the poetry and music literature of traditional gymnasium as a component of this interconnected whole, have a huge effect. Traditional gymnasium is a training place for athletes and in this regard, poetry and music are tools that have each used their best forms for this teaching. It seems that survey and field studies on this issue should be considered by researchers in the field of sports science.

Keywords: Poetry, Music, Ancient Sports, Zurkhaneh

Resumo: O objetivo deste artigo é investigar o efeito da poesia e da música nos esportes antigos no Irã. Como patrimônio cultural, o tradicional ginásio iraniano "Zurkhaneh" pode ser entendido de forma correta e abrangente quando, além do que se vê do ponto de vista da ciência atual, é transcendido, medido e analisado no campo do pensamento e da civilização que tem emergiu dele. Este estudo foi um campo e estudos de biblioteca. Uma revisão da literatura poética mostra que o antigo esporte iraniano remonta aos medos e à era pré-islâmica. Entre os poemas tradicionais de ginásio, os poemas relacionados com o louvor a Deus, o louvor ao Sagrado Profeta Maomé e o louvor ao Imam Ali, o primeiro Imam Shia, têm um papel especial na música nos esportes antigos. A letra e a música ficam cada vez mais próximas da vida das pessoas, contando com princípios simples e fáceis, para fazer com que as pessoas sigam as palavras e coloquem as palavras na cabeça. A música no esporte antigo foi escolhida de forma que o mentor possa improvisála e memorizá-la com facilidade. O estudo sobre a influência da poesia e da música nos esportes antigos confirma que; o ginásio tradicional, como espaço cultural, e a poesia e a literatura musical do ginásio tradicional como componente deste todo interligado, têm um efeito enorme. O ginásio tradicional é um local de treino de atletas e neste sentido a poesia 
e a música são ferramentas que cada um tem utilizado as suas melhores formas para este ensino. Parece que levantamentos e estudos de campo sobre essa questão devem ser considerados por pesquisadores da área de ciências do esporte.

Palavras-chave: Poesia, Música, Esportes Antigos, Zurkhaneh

Resumen: El propósito de este artículo es investigar el efecto de la poesía y la música en los deportes antiguos en Irán. Como patrimonio cultural, el gimnasio tradicional iraní "Zurkhaneh" puede entenderse correcta y exhaustivamente cuando, además de lo visto desde el punto de vista de la ciencia actual, se trasciende, se mide y analiza en el campo del pensamiento y la civilización que ha emergió de él. Este estudio fue un estudio de campo y de biblioteca. Una revisión de la literatura de poesía muestra que el antiguo deporte iraní se remonta a los medos y la era preislámica. Entre los poemas tradicionales del gimnasio, los poemas que están relacionados con la alabanza de Dios, la alabanza del Santo Profeta Mahoma y la alabanza del Imam Ali, el primer Imam chiíta, tienen un papel especial en la música de los deportes antiguos. La letra y la música se vuelven más fáciles y cercanas a la vida de las personas, basándose en principios simples y fáciles, para que las personas sigan las palabras y las pongan en sus mentes. La música en el deporte antiguo se ha elegido de tal manera que el mentor pueda improvisarla y memorizarla fácilmente. El estudio sobre la influencia de la poesía y la música en los deportes antiguos confirma que; El gimnasio tradicional, como lugar cultural, y la poesía y la literatura musical del gimnasio tradicional como componente de este todo interconectado, tienen un efecto enorme. El gimnasio tradicional es un lugar de entrenamiento para deportistas y en este sentido, la poesía y la música son herramientas que cada uno ha utilizado sus mejores formas para esta enseñanza. Parece que los investigadores del campo de las ciencias del deporte deberían considerar encuestas y estudios de campo sobre este tema.

Palabras clave: Poesía, Música, Deportes Antiguos, Zurkhaneh 


\section{Introduction}

Iranian Ancient sport, as its name suggests, is one of the special methods of physical training of Iranians, which has been invented, developed and continued as a multidimensional sport, cultural and artistic system (PARTO BEIZAI KASHANI, 2003). This system includes the elements of both physical and spiritual sides of the sports like moral, educational, physical fitness, bodybuilding, and cheerfulness, music, architecture, aesthetics and specially culture. This sport has been preserved during the ups and downs of the history of Iran and those interested and nurtured in its presence have had special effects on the moral, social and even political life of this land. From the perspective of anthropology, the culture of heroism and chivalry has been considered as one of the basic dimensions of Iranian culture and chivalry has always been associated with ancient sports (HOSSEINI, 2008).

Fig 1. Iranian athletes in Qajar Era (Source: RAJABI, 1977)

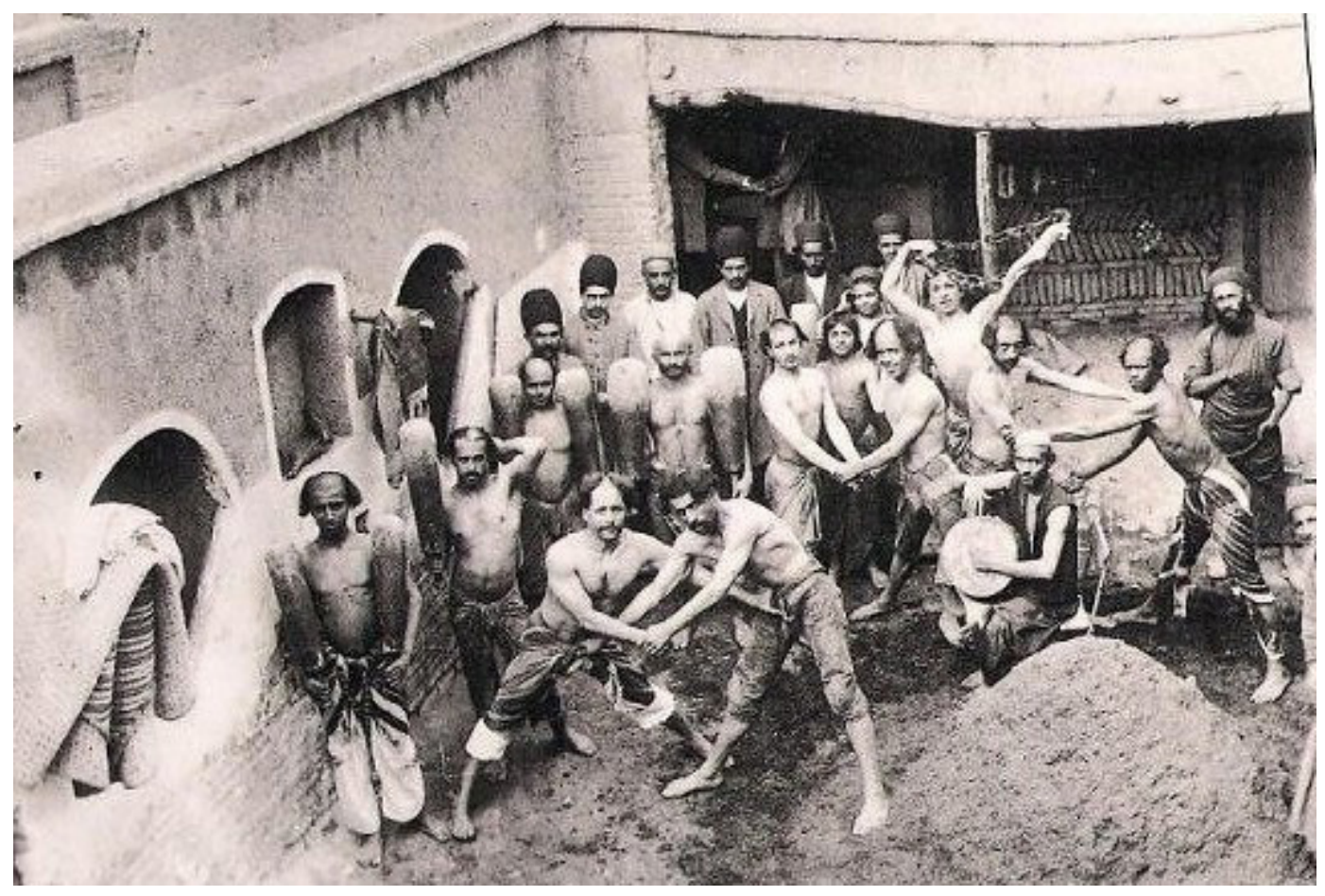


One of the oldest Iranian sports is called the ancient sport. The main content of the educational art is ethics, wisdom and teaching. In our past works, various names such as asceticism, research, and advice, wisdom, preaching and teaching have been used for educational literature and traditional gymnasium, in order to achieve this content, forces each of its components (music and literature) to take a step in the direction of its goal, which is education (RASTEGAR FASAEI, 1993). Since the audiences of Zurkhaneh are the ordinary people, they choose a language that is simple, tangible and as understandable as possible for everyone. The purpose of this study is to analyze the phenomenon of "traditional gymnasium" or Zurkhaneh as the outcome of old traditions in Iran (AFSARIAN, 2016). It is true that in ancient sports, functional tools were inspired by war tools. For example, "Indian club" is a modified form of a mace, " bow-shaped iron instrument used in gymnastics" is the same as a "bow", " traditional gymnasium's stone" is the same as "shield", and "traditional gymnasium's drum" is reminiscent of a war drum or a bass drum and the playground of traditional gymnasium is a place for cultivating the body and soul. But in the meantime, reading the poems of the same sentence has played the role of bragging about the battlefields. With the difference that in the poems of arrogance, the aim was to frighten the opponent and overcome him. But in the lyrics and the music in traditional gymnasium, is used to instill power and strength in the athletes; in the meantime, they considered the desired poems with a hint of advice and counseling in the path of overcoming the soul (ELAHI, 1994). Many researches have been accomplished to clarify the origins of this sport. Perhaps one of the most important reasons for this is the secrecy of this sport and the existence of special customs in it (HEYDARI AND DOLATSHAH, 2012). Traditional gymnasium, as a place for teaching masculinity and generosity etiquette, is a "teaching" phenomenon in Iranian-Islamic culture, which has used other components, including music, in this regard (FUZUNI, 2015). According to the "educational" features, traditional gymnasium's educational music provides a tool for teaching to create a general phenomenon called "traditional gymnasium" along with other 
elements (AFSARIAN, 2016). The overall purpose of this study was to investigate the educational role of poetry and music in ancient sports.

Fig 2. Athletes perform ancient sport outside of Zurkhaneh. (Source: RAJABI, 1977)

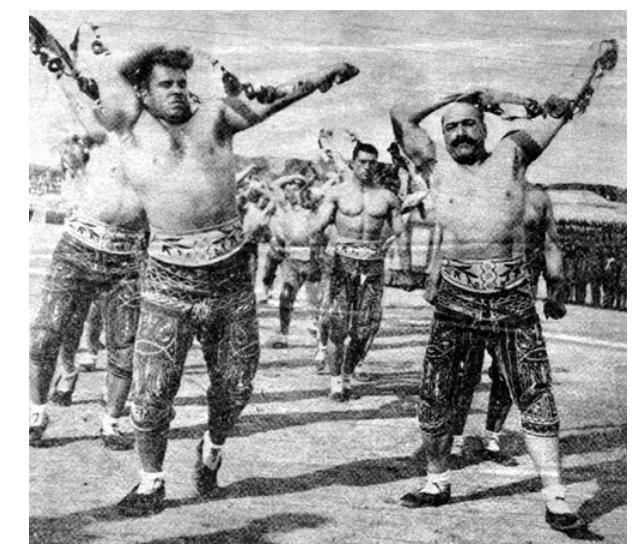

\section{Zurkhaneh or the traditional gymnasium}

Traditional gymnasium, in its educational function, studies two influential components in it and in addition this view, by referring to the examples, it achieves a separate conclusion about "how" these view (AFSARIAN, 2016). The examples studied in this article are the two fields of "poetry literature" and "music" which were studied in two general sections (FUZUNI, 2015).

Traditional gymnasium's ultimate goal is the education of body and soul. Most of the research records are related to traditional gymnasium customs and terms. Among them, they can mention the book "Ancient Sports Education" by Farhad Toloo Kian (2010), which examines the history, culture, customs, place and tools of ancient sports. Hayedeh Sirafi in the article "The Impact of traditional gymnasium Literature on Popular Culture" explores the proverbs influenced by traditional gymnasium and finds the roots of traditional gymnasium terms. Mostafa Sedighpour in the 
article "Ritual of chivalry, traditional gymnasium and ancient sports in the course of history" (2008) examines the historical course of traditional gymnasium before and after Islam. Ali Jahanpour in his article "Rituals and Beliefs of traditional gymnasium" (2008) examines the stories and beliefs of traditional gymnasium in the city of Hamadan. Other research records in the field of traditional gymnasium music include the book "Sports Rhythms" (traditional gymnasium Rhythms) by Faramarz Najafi Tehrani (1991), which provides an overview of the traditional gymnasium multi-rhythm and the history of traditional gymnasium. Among the research records in the field of history, we can mention the article of Insafpour (1974) in the book "History and Culture of traditional gymnasium". In the first part, he examines the historical roots and social role of ancient sports from pre-Islamic to the end of the Qajar period. The second part is a dictionary of traditional gymnasium terms and the third part is a summary of how ancient sports operations and the rhythm of each beat are summarized. Mehrdad Bahar (1977) in his article "The Rite of Love and Ancient Sports of Iran", which was an introduction to the book "Socio-Cultural Study of Tehran's traditional gymnasium", compares traditional gymnasium and places of worship of love and he considers the architecture of the Iranian traditional gymnasium as a long and steep slope and influenced by the ritual of kindness thinking. In his article "Another Look at the Ancient Tradition: traditional gymnasium", Sadr al-Din Elahi criticizes two theories related to the history of the formation of traditional gymnasium. Afsarian (2016) in his article "Architecture and Educational Music in traditional gymnasium" deals with the relationship between architecture and educational music and the manifestation of architecture and music in traditional gymnasium. 
Fig 3. Athletes Gesture in front of the camera (Source: RAJABI, 1977)

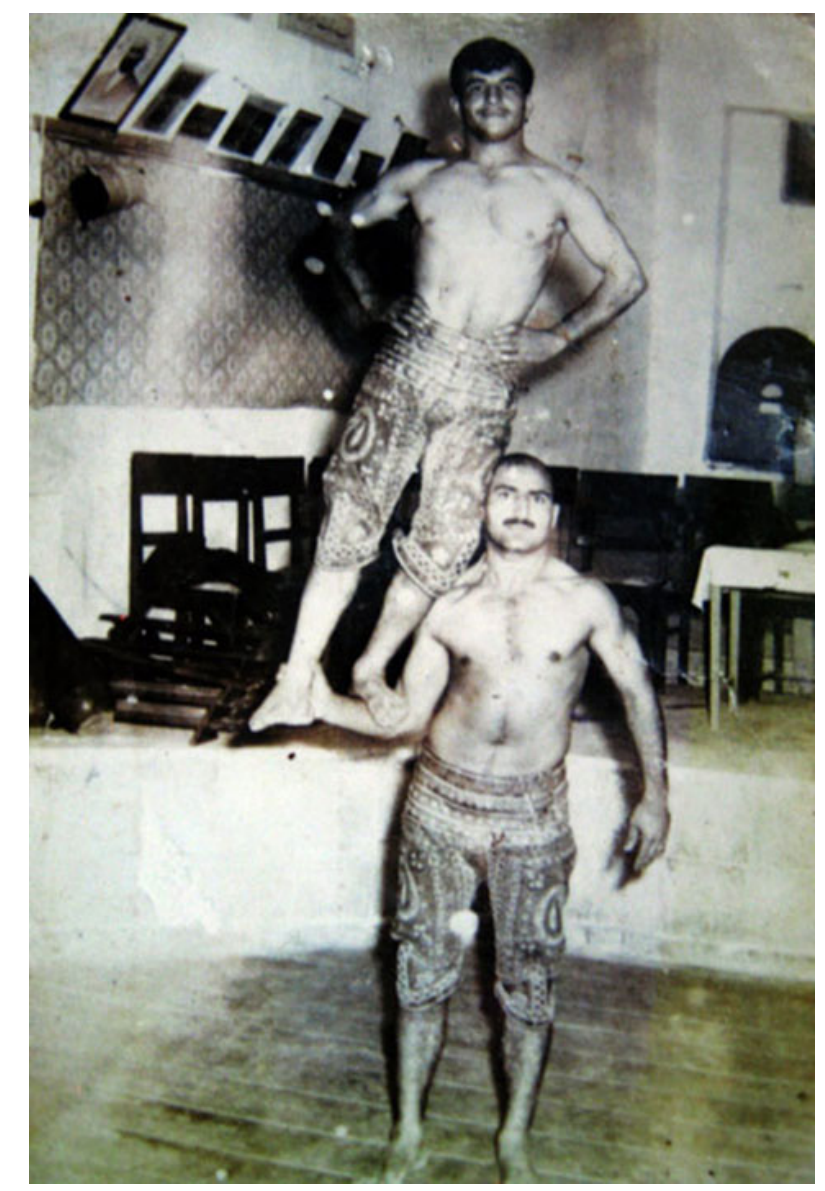

\section{Morshed or mentor}

Morshed is an artist with a moral and instructive personality who has the highest position in Zurkhaneh. While reading epic poems, he guides the athletes by playing the percussion (AMINIZADEH AND BUSTANI, 2013). Mentor is the pillar of traditional gymnasium tent and is the most important and honorable place by playing its rhythmic beat and words to guide and coach the athletes. The mentor of traditional gymnasium must be a pious, humble, polite, knowledgeable, careless, literate person, aware of the etiquette of traditional gymnasium sports and overlook all aspects of religious culture, poetry, etc. A mentor must have a sweet accent and musical genius. The mentor has to be generous and kind 
and he observes the rights of each individual in play ground. The character of the mentor is multi-dimensional, someone who has a deep understanding of religion and is always the guardian of morality in Zurkhaneh. He should be on the platform of guidance and guidance so that his behavior, actions and speech should be a model for others (TOLO KIAN, 2010). The mentors, who mostly appeared in traditional gymnasium after the Safavid era and were remembered until the early Qajar period, In addition to having a good and expressive voice, they should be able to harmonize the poem, the "veterans" with the title of rhythm and the art of singing, because the poems read in traditional gymnasium are epic poems whose rhythms are used. This "Shahnameh of Ferdowsi", that is, the weight of the poems "The Convergent poetical measure" has a special rhythm and is often sung in "Gol Charkh" and "Gol Kesht", the war poems that are louder and more with percussion songs (GOODARZI, 2004) Interestingly, in addition to reciting "Prayer for the End of Exercise" and "Request for permission", "Rightseeking" mostly includes what is used in traditional gymnasium as poetry. Ferdowsi's poems are different poems from poets like him. These poems, while praising the great "Pouria Vali" or "Pahlavan Mahmoud", invite athletes to Request for permission worldly belongings and join spirituality (SIDDIQ IMANI, 2008). Traditional gymnasium, as a place for teaching masculinity, is a "teaching" phenomenon in Iranian-Islamic holistic culture and thought. It has also used other components such as music in this regard. Traditional gymnasium's music has features such as simplicity, populism, and ease of access that bring it closer to all social classes and provides a tool for teaching the moral values to create a general phenomenon called "traditional gymnasium" along with physical elements (AFSARIAN, 2016).

\section{Poems and rituals}

In traditional gymnasium, the poems have an epic and religious taste. Religious poems deal more with the human mood (KAZEMINI, 
1343). Since these poems are about the Shiite Imams, they create a spiritual state in the atmosphere of traditional gymnasium. Such circumstances lead to the strengthening of the religious identity of these religious poems, which we Shiites are influenced by, and remember the massacre pit (the place where Imam Hussein was beheaded). These poems also make us interested in poetry" (ROSHAR, 2004). National and epic poems describing Iran and Iranian heroes, while religious poetry is more emotional, it includes religious sentiments and the praise of the Imams. National and epic poems are mostly rooted in the Shahnameh and motivate and energize archaeologists. The epic poems of national pride reinforce the nationalist feeling and motivation in the antiquity of the work and lead to the prominence of their national identity. In fact, the roots of both types of poems go back to tradition (NAJAFI AND HEJAZI, 1991). Beck (1994) states in a study that; Tradition tends to have a past, just as the past has a very strong influence, that is, the past is made to have a strong and deep influence on the present. Since both types of poems deal with the athlete's emotions and emotional aspects, they have a profound effect on the individual's identity. Traditional gymnasium games teach people humility, order, respect, self-sacrifice, politeness and generosity. It is common behaviors and actions in traditional gymnasium that are institutionalized by repetition and practice in individuals. This impact is so profound that it shapes the athlete's behavior outside the traditional gymnasium and among the people (FUZUNI, 2015).

\section{Traditional gymnasium Literature}

Poems sung by the mentor in the traditional gymnasium comes along with an Iranian percussion called Zarb, Gol Charkh, Gol Kesht, or poems such as: Right-seeking, Request for permission, and even the pray for the end of training performed by Miandar, form the "traditional gymnasium literature." Traditional gymnasium lyrics can be divided into three main groups: the first group is epic and heroic lyrics, at the top of which are the poems of Ferdowsi's 
Shahnameh, and it is really a sea of moral, patriotic and martial poems. The weight of these poems is in the Convergent poetical measure, which is very suitable for four-stroke sports movements. In the words of Dr. Rezazadeh Shafaq: "The stories of Iranian heroes remind us of lessons of courage, modesty, sacrifice, patriotism and loyalty, and awaken every Iranian in love, affection and a sense of duty to Iran, which is a relic of ancestry." The second group is the lyrics by famous Persian poets which have an epic theme. These poems are morally and mystically very instructive and valuable. Among these poems, the most common is the use of the Imam's eulogy, especially Imam Ali.

Fig 4. Athletes gesture in the playground pit while Morshed is seen holding a Zarb in the middle (Source: DARVISHI, 2005)

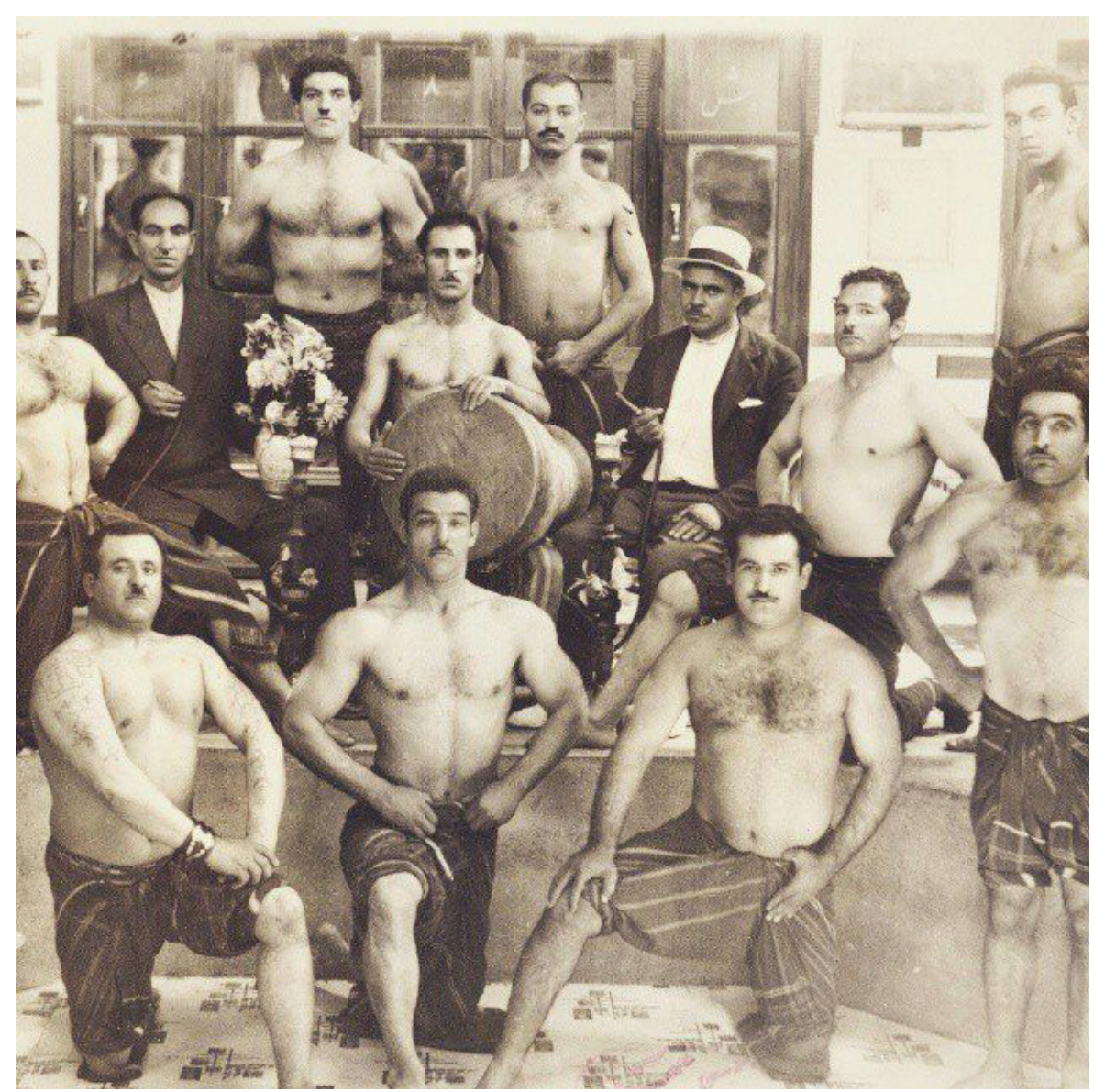


Of course, there are many examples of these poems in the divan of most famous poets, and there is no need to continue talking and giving examples about this, and everyone is aware of it. The third group is poems dedicated to heroes, whose poets were mostly ancient athletes and heroes, and were able to cope well with the terms and themes related to traditional gymnasium. Such as: "Gol Charkh", "Gol Kosht", "right- seeking", "Request for permission", "reading the quatrain" and the like. The most famous heroic poets, in the first stage, are Mohammad's heroes known as "Pouria Vali". He is well-known in the heroic school and was nicknamed "Ghatali", and his poems are especially popular among the mentors. In tazkerat al- majales aloshagh written by Kamaluddin Sultan Hosseini one of the descendants of Amir Timur, who lived about 150 years after Pouria Vali, has narrated poems by Pahlavan Mahmoud, which we quote here from the history of Beizai sports (TEHRANCHI, 2009).

Ancient sports have their own rules and traditions. Traditions which are based on heroes and legends of the ancient period and leads to masculinity and chivalry in athletes. (ABBASI, 2008). Ferdowsi and Shahnameh are two great names that, in addition to introducing the culture and history of this land, strengthen the sense of pride and self-confidence in Iranians and open an accurate identification of the historical past of Iranians to the reader's eyes. In the Shahnameh, we read that the class of heroes from the time of the discovery of fire by Jamshid, and after the clergy class. This class has been responsible for maintaining the territorial integrity of the country and the monarchy and defending the land and the honor of the people of their homeland. To do their job and perform the assigned functions, the heroes needed to know the art of war more than anything - apart from spiritual and spiritual issues. An art by which, while acquiring physical and physical abilities, they will be able to use the tools and equipment of warfare of that time such as spears, swords, bows and arrows and necessary combat skills such as riding, wrestling, push up and mountaineering (FUZUNI, 2015). It was not possible to learn "martial arts" without special 
training. These teachings were not limited to material issues and the study of technical and physical arts, and in that course, the ethics and character of heroism were of great importance. In his valuable book Shahnameh, Ferdowsi has spoken about all aspects of being Iranian, and his special attention to heroism and character and its method have distinguished this work from other literary books. As sports, sports tools, and its cultural and popular status in the Shahnameh are important issues that cannot be ignored. These good traits, in the form of melodic poems and stories, and along with the beats of traditional gymnasium music provoke and arouse athletes during sports. Athletes, in harmony with the music and beat of the Morshed, perform beautiful and harmonic group or individual movements (AFSARIAN, 2016).

\section{Traditional gymnasium's music}

Traditional gymnasium's music includes a set of vocal based on epic lyrics as well as an old Iranian rhythms. Traditional gymnasium's music, despite all the changes that seem to have taken place in recent decades, still contains major parts of Iran's past musical culture. In music, this convergence of seemingly contradictory elements is formed by the content of the words in the performance of the guide. Music in traditional gymnasium includes a huge range of beats, melodies, rhythms and lyrics (AFSARIAN, 2016). 
Fig 5. Athletes play to the rhythm of music (Source: DARVISHI, 2005)

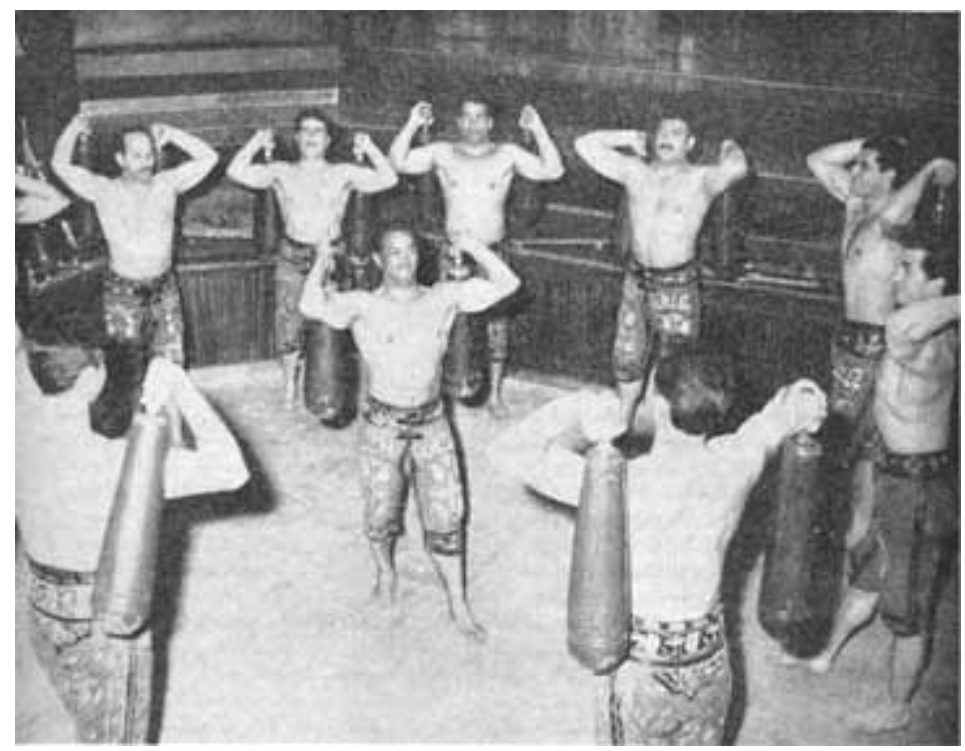

\section{Heroic song}

"Heroic song" or "Gol koshti" or "Ghol Koshti" is one of the most famous forms of mystical and epic verses performed by a mentor or Morshed. This song is a kind of instructive and praiseworthy speech that is accompanied by literary, mystical and epic quotations" (TOLO KIAN, 126). For example the "heroic song" is a mixture of three elements of poetry, rhythm and song is in one beat. Because it was called a wrestling match, it was also called a wrestling goal: "The wrestling was special for the great wrestlers and the claimant. One decided to defeat the other and asked for a ship. "Naturally, for such an important event, the generals and wrestlers would gather in traditional gymnasium, and the guide would recite the poem" Gol koshti. "( SIDDIQ IMANI, 2008). This beat not only has a rich connection between poetry and music, but also has historical roots based on the epic lyrics. In the following, traditional gymnasium's beat of "heroic song" is based on melodic characteristics, rhythm and inner rhythm of the poems. It should be noted that this beat has been studied with three samples that 
have been performed by the top three instructors in the country: Melodic characteristics in the analysis of the construction of a melody, the four main characteristics of the melody are examined. These characteristics include: Musical intervals, Scale and modalities, Melodic movement, Combination of melodic intervals and scales, Tonality and harmony. This kind of Music consists of a melody with minimum notes and a kind of minimal harmony. The melody movement represents the continuity of the melody and simplicity in all performances. Avoiding consecutive jumps in beats that leads to the continuity and integrity of the melody. Since singing has the semantic burden of poetry and has a high and wide place in traditional music (SHAMISA, 2002), it is expected to be present in traditional gymnasium music with a brilliant presence of mentor 's vocal. But in singing, decorations, tremolo and trill have been avoided. The melody of the song emphasizes on the rhythm and the beat of the music rather than the vocal ornaments. The flow of melodies and the movement of the song are set to be like a loop and the melody returns to its starting point again and again (AZADEHFAR, 2015). This balance between the up and down flow of the melody leads to a kind of melodic symmetry that is musically, easier and faster in the mind of the listener and the melody will last longer. With this melodic symmetry, music seeks to pursue a goal, which is to engrave the melody and lyrics in the listener's mind (TAMOLI, 2012). In all three heroic songs, the initial fashion change does not occur. This adherence to the original fashion reveals a kind of stability and color throughout each performance. Music avoids changing beats and themes and seeks variety in rhythmic passages. In most of the songs singing back by the crowd has been used. This technique reveals a kind of action and reaction within the melody itself. This circular and recurring movement creates a kind of simplicity and pleasant repetition of sounds in the listener's mind (AFSARIAN, 2015). 
Fig 6. Morshed or mentor plays Zarb and Bell in a Zurkhaneh (Source: DARVISHI, 2005)

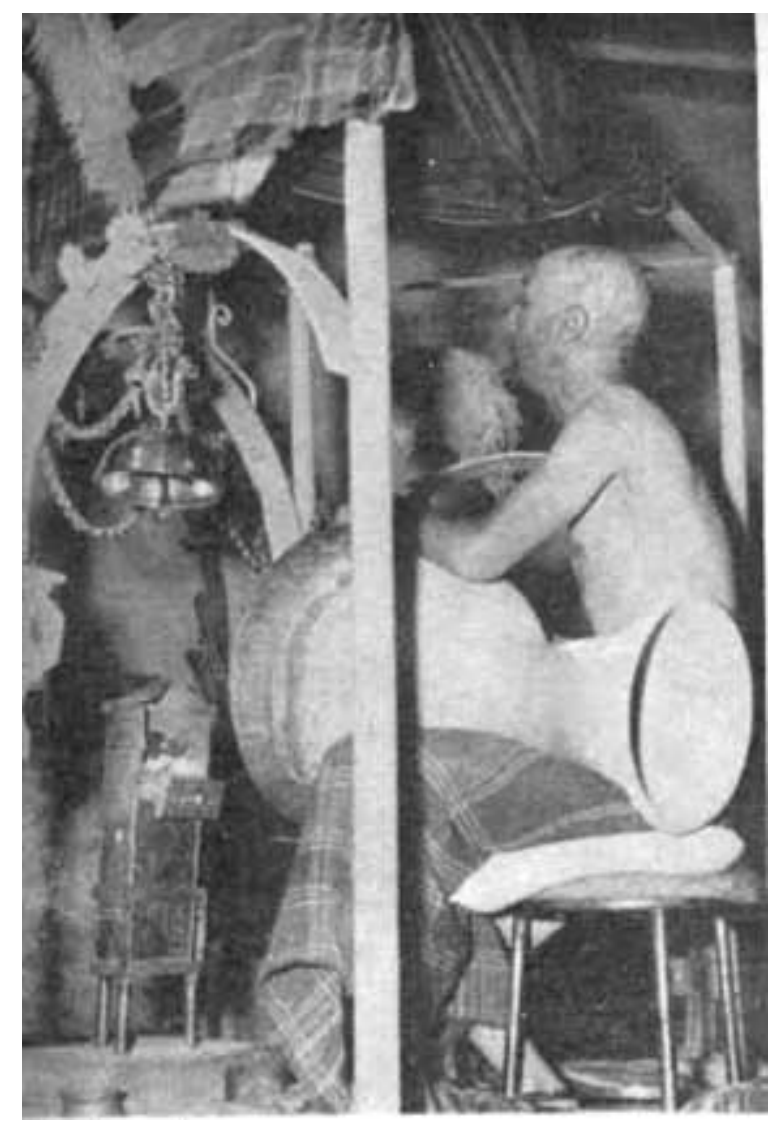

\section{Melody and rhythm}

By juxtaposing the melody of all three performances, we achieve similar rhythmic patterns (AZADEHFAR, 2015); using a time tension similar to these traction results in a rhythm similarity in all three performances. In terms of vocal vocabulary, all three performances follow a very close rhythmic pattern. The use of minimal rhythmic figures indicates the simplicity of the melody. The melody has been formed and expanded with the simplest temporal stretches (AFSARIAN, 2016). In general, the main basis of all sports movements in traditional gymnasium, from head to toe rock, push up, desire, desire to play, wheel, bow-shaped iron instrument used in gymnastics, etc. are the rhythms performed 
The Effect of Poetry and Music on Ancient Sports in Iran

Bisotoon Azizi • Mohammad Mohammadi • Nima Deimary • Seyed Ali Mir Shahvelad

by Tonbak. Common rhythms performed in traditional gymnasium are mainly: 6/8, 4/6, 4/4, 3/4, 2/4 (MOHSEN SHAHNAZDAR 2018).

Fig 7. The harmony of the athletes play in the pit (Source: DARVISHI, 2005)

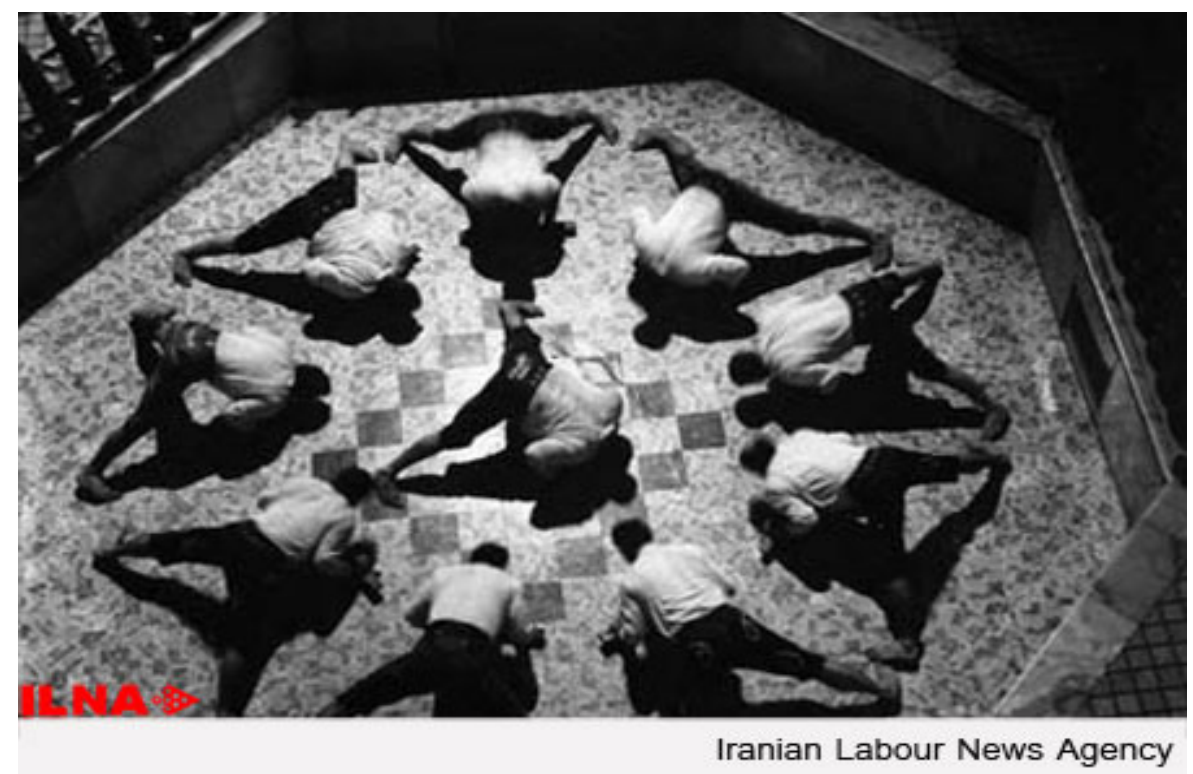

\section{The inner rhythm of the poems}

One of the defining elements of the rhythm of music in poetry is the rhythm of poems. The inner rhythm of the lyrics determines the beat of the music. The rhythm of poems recited in all three instances is the sea of "Convergent poetical measure." This sea,

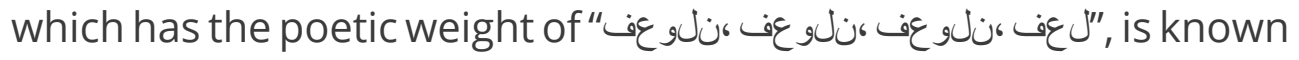
as "epic" weight. The use of "epic" weight in all three performances is a kind of confirmation of the appropriateness of poetic weight with the theme of traditional gymnasium music (FUZUNI, 2015). The use of this weight, on the one hand, helps the mentor in using the classic examples of Persian poetry with moral and epic themes, and on the other hand, it is a weight that is easy to remember. The use of symmetrical and continuous melodies, lack of vocal trills and tremolo decorations based on simplicity, makes the poetry more powerfully and that 's what is desirable for traditional gymnasium 
music, to make the epic lyrics more memorable (TAMOULI, 2012). Therefore, the repetition of simple and short motifs in the process of melodies, the lack of vocal decorations, as well as the choice of the Masnavi form of the slogan have been chosen to make it easier to understand, digestible and tolerable simplicity for the general audience. What has been considered as the ultimate goal in traditional gymnasium is to refer to the background and teachings that continue to this day (SEDIQ IMANI, 2008). The study shows; The holistic thinking of the builders of the traditional gymnasium has been calculated in such a way that they have put all the things mentioned in the traditional gymnasium in their minds and thoughts in the service of one goal, and that has been nothing but teaching morality and human character. Body and the soul of the architecture and music in Zurkhaneh are like objective and subjective aspects of this place (AFSARIAN, 2016).

\section{Conclusion}

The architecture of Zurkhaneh has its roots in the Mithraic temples and after the advent of Islam, due to the need to protect the country from the invasions of foreign enemies, it continues to function and attracts heroes and knights who are ready to help the weak and the poor in any situation. With the help of sports exercises, and epic poetry and music performed during these sports movements to prepare the minds and souls of athletes with epic poems for righteousness and honesty.

The study of the influence of poetry and music in the sport of Zurkhaneh, based on the holistic vision of the traditional belief, confirms that Zurkhaneh as an architectural masterpiece and music and poems as components of this interconnected whole, create a proper place for training the athletes whose educational effects are evident on different generations for many centuries. Zurkhaneh poetry and music, in addition to its educational role, with simple melodic forms and lyrical motifs and attractive contents based on 
epic rhythms, have brought rich themes of Iranian music to the listener and by repeating and emphasizing the athletic exercises along with the use of the epic music. Simple and catchy poems inspired by epic theme provokes the warrior spirit of the audience to strengthen the motivation to defense the homeland in the hearts of athletes. Zurkhaneh is a place for training and learning of athletes and in this regard, music is a tool that uses its best forms and shapes for this training in combination with poetry.

\section{References}

ABBASI, Houshang. The Art of Living and Living: Traditional Sports and Games, a Symbol of Social Life A Look at Two Books, No. 123, 2008, pp. 31-26.

AFSARIAN, Seyed Sobhan. Architecture and Educational Music in Traditional gymnasium, Bagh Nazar Magazine, 13, No. 42, 2016, pp: 88-79.

AMINIZADEH, Sina, Dariush's garden. "Traditional gymnasium and its identification sources", Social Development Quarterly, No. 1, Volume 9, Pages: 76, 2014.

AZADEHFAR, Mohammad Reza. Fundamentals of Melody Creation in composing melody .Waiting for publication. 2015.

BAHAR, Mordad. Mehr ritual and ancient sports (comparison of Traditional gymnasium and Mehri shrines), Hafez, 88, 2012, pp: 1612.

ELAHI, Sadr al-Din. A Look at the Ancient Tradition: Traditional gymnasium, Iranian Studies, Year 6, 1994, pp. 745-726.

GOODARZI, Mahmoud,. The Evolution of Ancient Sports and

Traditional gymnasium in Iran, Harakat, 22, 2004, pp. 170-150.

HEYDARI, Ali, Dolatshah, Nasser. The Effects of Sufism, Photot and

Shiite Religion in Ancient and ancient Sports in Iran, Two Quarterly 
Journal of Research in Sports Management and Motor Behavior, 2017, $60-58$.

HOSSEINI, M. ancient Sport: it `s role in social parameters and it `s Globalization. Bamdad Publication; Tehran, Iran, 2008.

INSAFPOUR, Gholamreza. History and Culture of Traditional gymnasium and Social Groups, Akhtar book Publishing Company, First Edition, Tehran, 2007.

JAHANPOUR, Ali. Traditional gymnasium Religions and Beliefs, Quarterly Journal of People's Culture, especially Hamedan, Sh., 26, 2008. KAZEMINI, Kazem,. The Role of Heroism and the Ayari Movement in the Social History and Political Life of the Iranian Nation: Definition of Traditional gymnasium and Analysis of Ancient Sports. Tehran: Bank Melli Iran Printing House, 1964.

MOSTAFA, Siddiq. Good Hole - The Origin of Traditional gymnasium Art and People, 1974, pp: 145-9.

NAJAFI Tehrani, Faramarz and Assadollah Hejazi. Sports Rhythms) Y a Traditional gymnasium Rhythms), Tehran: Part. 1991.

PARTO BEIZAI KASHANI, Hossein. History of Ancient Iranian Sports (Traditional gymnasium). Tehran: Pilgrims. 2003.

RASTEGAR Fasaei, Mansour. Types of Persian Poetry, First Edition. Tehran: Navid Shiraz Publications, 1994.

ROSHAR, Philip. Traditional gymnasium Identity. T: Amir Tawfiqi. Conversation, 2004, pp: 75-74-42.

SARGHIN, Maryam. A Study of Traditional gymnasium Literature and Poetry, National Conference on New Research in Sports Science. 2015.

SHAMISA, Cyrus. literary genres. Third Edition, Ninth Edition, Tehran: Ferdows Publications. 2002.

SIDDIQ IMANI, Mostafa. The Rite of Manhood of Traditional gymnasium and Ancient Sports in the History, Art Book of the Month of Art, No. 121, 2008, pp. 57-42. 
SIDDIQ Imani, Mostafa. Traditional gymnasium chivalry and ancient sports in the course of history. Book of the Month of Art, 121, 2008, pp: 54-42.

SIRAFI, Hayedeh. "The Impact of Traditional gymnasium Literature on Public Culture (Research on Proverbs Influenced by Traditional gymnasium)", Quarterly Journal of Physical Education Development Growth, No. 28, p. 10, 2008.

TAMOULI, Mehdi, Morshedi's education. Tehran: Ambassador Ardahal, 2012.

TEHRANCHI, Mohammad Mehdi. Ancient Sports from the Perspective of Value, Tehran: Amirkabir Publications, Second Edition, 2009.

TOLOO Kian, Farhad. Traditional gymnasium Sports Education, History, Culture, Etiquette, Place, Tools, Operations and Physical Benefits of Ancient Sports, First Edition, Tehran, Safir Ardahal Publications, 2010.

VAHIDIAN Kamyar, Taghi. weight and rhyme of Persian poetry, University of Tehran publisher, 1995.

RAJABI, Bahman. Tonbak and Attitude to Rhythm from Different Angles, Book One publisher. Tehran, 1977, page 48.

DARVISHI, Mohammad Reza. Encyclopedia of Iranian Instruments, Volume 2, Page 376, September 2005. 